\title{
ETERNITY AND VISION IN BOETHIUS
}

\author{
PAUL HELM \\ Regent College, Vancouver
}

\begin{abstract}
Boethius and Augustine of Hippo are two of the fountainheads from which the long tradition of regarding God's existence as timelessly eternal has flowed, a tradition which has influenced not only Christianity, but Judaism and Islam too. But though the two have divine eternality in common, I shall argue that in other respects, in certain crucial respects, they differ significantly over how they articulate that notion.
\end{abstract}

Boethius and Augustine of Hippo are two of the fountainheads from which the long tradition of regarding God's existence as timelessly eternal has flowed, a tradition which has influenced not only Christianity, but Judaism and Islam too. ${ }^{1}$ But though the two have divine eternality in common, I shall argue that in other respects, in certain crucial respects, they differ significantly over how they articulate that notion. Most of our space will be devoted to what Boethius has to say in the locus classicus of his views, Book V of The Consolation of Philosophy, and to some of its rather unfortunate implications. I shall conclude, after a shorter discussion of features of Book XI of Augustine's Confessions (the other classic source), that Boethius would have been wiser to take Augustine's tack.

Book V of the Consolation is devoted to Boethius's attempt to offer an account of providence, in particular his attempt to reconcile God's infallible knowledge of the future with human agency, sin and merit. Boethius famously illustrates the relation of the timelessly eternal God's knowledge to the goings on of the temporal order by supposing that God surveys the whole of reality as we might see from the top of a hill all that is going on in the valley below. Divine providence is far removed from matters below and looks forth at all things as though from a lofty peak

${ }^{1}$ For example David Burrell, CSC, Freedom and Creation in Three Traditions (Notre Dame, IN: University of Notre Dame Press, I993).

European Journal for Philosophy of Religion i (2009), PP. 77-97 
above them'. ${ }^{2}$ As I shall argue, for Boethius such a reference to perception is more than a casual comparison, a disposable figure of speech. By the time that the careful reader of the Consolation has reached the end of Book $\mathrm{V}$ he will have realised that a fairly precise idea of divine perception has been woven into the centre of Boethius's account of divine eternity, and contributes quite a bit to furthering the apologetic purpose of that account. Boethius draws the parallel between divine knowledge and visual perception many times throughout Book V of the Consolation.

He says that God's knowledge

... embraces all the infinite recesses of past and future and views them in the immediacy of its knowing as though they are happening in the present. If you wish to consider, then, the foreknowledge or prevision by which $\mathrm{He}$ discovers all things, it will be more correct to think of it not as a kind of foreknowledge of the future, but as the knowledge of a never ending presence. So that it is better called providence or "looking forth" than prevision or "seeing beforehand." For it is far removed from matters below and looks forth at all things as though from a lofty peak above them. ${ }^{3}$

God 'foresees', he has 'pure vision', he gazes down on all things, 'you cannot escape divine foreknowledge just as you cannot escape the sight of an eye that is present to watch, ${ }^{34}$ and so forth. Since according to Boethius divine intelligence enjoys 'the highest form of knowing', 'boundless immediacy', God's eternal knowledge is like immediate visual perception.

Boethius's central contention can be expressed (in his own words) as follows. God's knowledge

does not change the nature and property of things; it simply sees things present to it exactly as they will happen at some time as future events. It makes no confused judgments of things, but with one glance of its mind distinguishes all that is to come to pass whether it is necessitated or not. Similarly you, when you see at the same time a man walking on the earth and

2 Boethius, The Consolation of Philosophy, trans. V.E. Watts (Harmondsworth: Penguin, I969), I65.

3 Consolation, I65. Boethius here says that God knows things 'as though they were happening in the present', suggesting perhaps a rather different account of divine timeless eternity. But his central view is clearly eternalist.

${ }^{4}$ Consolation, 168.

${ }^{5}$ Consolation, 162. 
the sun rising in the sky, although the two sights coincide yet you distinguish between them and judge the one to be willed and the other necessitated. In the same way the divine gaze looks down on all things without disturbing their nature; to Him they are present things, but under the condition of time they are future things. ${ }^{6}$

Of course Boethius did not think that God has eyes, but strangely this fact did not lead him to qualify the language of visual perception. Many in the tradition of regarding God's existence as timelessly eternal have thought of it more sparingly than Boethius did and have often preferred negative ways of expressing God's atemporality. By comparison Boethius is much bolder. To speak of God's immediate visual perception must be an analogy, we may think, and yet Boethius did not treat it as one. As we shall eventually see, he appeals to the idea of immediate visual perception for at least two reasons.

When Boethius said that God is eternal he did not mean that God exists at all times. He is sensitive to the distinction between the 'everlasting life' that the world has if (as Plato believed) it had no beginning in time and will have no end, and (divine) eternity which embraces 'the whole of everlasting life in one simultaneous present' . 'That is, Boethius holds that even if the world is backwardly everlasting and forwardly everlasting, and so in a sense 'eternal', nevertheless the world embodies a temporally successive order, and so exists sempiternally. By contrast God embraces the whole of (such) everlasting life in 'one simultaneous present'. 'God is eternal, the world perpetual.'8

Nevertheless, God knows the temporal order in accordance with his nature, and (Boethius appears to argue) it is because God is timelessly eternal that he is able to know that entire order immediately in the sense that he knows it nonsequentially. He does not know one event and later another, then later another, and so on.

His knowledge, too, transcends all temporal change and abides in the immediacy of His presence. It embraces all the infinite recesses of past and

\footnotetext{
${ }^{6}$ Consolation, I66.

7 Consolation, 164

8 Consolation, I65
} 
future and views them in the immediacy of its knowing as though they are happening in the present. ${ }^{9}$

Martha Kneale thought that this is incoherent. The spectator on the top of the hill sees the road beneath all at once, but he does not see the person walking in all positions at once; hence she thought that Boethius's analogy is crucially flawed. ${ }^{10}$ Of course this is to interpret timeless eternity as totum simul; everything is present to the divine mind at the same moment, simultaneously. But such a way of thinking about timelessness is less than fully consistent and is not, I believe, warranted by the main thrust of Boethius's views. For as we have seen, for Boethius God knows everything but not at the same temporal moment because there are no such moments in the eternal life of God. For Boethius the 'at once' is not the 'at once' of time but the 'at once' of non-successiveness. God is eternally present to the whole of reality that lies before his 'gaze'.

Nevertheless, if Boethius really does insist on the immediacy of God's knowledge then it may seem that his apologetic for divine providence is jeopardised, because that apologetic requires God to see the entire created order non-sequentially. The foreknowledge of God, which in Boethius's view places human freedom in question, has to be eliminated, and Boethius's way of effecting this is to appeal to God's timeless gaze. But further, if God truly does see the entire order non-sequentially then it may seem that that is how the events of that order are, non-sequential. For God knows (by non-sequentially seeing); hence that is how what he sees must be, non-sequential. So by appealing to immediacy it appears that Boethius jeopardises the true temporality of that order. Accepting the sequential character of the temporal order as illusory would seem to have the unfortunate consequence (inter alia) of undermining the reality or efficacy of human agency and of causal powers of all other sorts, and to involve a commitment to a kind of temporal immobility. So Boethius's view may carry the consequence not, as Mrs Kneale said, that everything happens at the same moment, but the rather different consequence that nothing happens at any moment. For if God immediately knows what is true of me next Tuesday

\footnotetext{
9 Consolation, $\mathrm{I}_{5}$

${ }^{10}$ Martha Kneale, „Eternity and Sempiternity“, Proceedings of the Aristotelian Society (I968-9): 227 .
} 
by non-sequentially knowing it, then the question is not how I now have the power not to bring it about that I will do something else next Tuesday-a question often discussed in connection with God's exhaustive knowledge of the future-but the more basic question: How do I now have the power actually to do what it is eternally known, by non-sequential knowledge of the entire created order, that I will do next Tuesday? On the visual analogy employed by Boethius God does not immediately know what I will do next Tuesday, nor what I am doing next Tuesday, he knows immediately what I non-sequentially do on that timelessly ordered Tuesday.

It might be said that the answer to this problem is straightforward: it is that God not only non-sequentially knows what I am doing next Tuesday, but that he also non-sequentially knows how it comes about that I will do whatever it is that I do next Tuesday: my decisions and plans, and the means that I am able successfully to take to implement my plans. He non-sequentially knows not only the ends, but also the means to effect these ends. But the retort to this is equally straightforward: how can God non-sequentially know that an event $\mathrm{X}$ is temporally prior to and causally sufficient in bringing about some later event if all events are eternally and non-sequentially seen by him? How can the reality of temporal precedence and of causal power be represented in the divine mind as it is if the divine mind exists timelessly and if the way to understand this representation is as a case of immediate perception? How can what is sequential be faithfully represented as non-sequential? If I bring about $X$, $\mathrm{X}$ does not occur until I bring it about. How then can my bringing $\mathrm{X}$ about exist as a percept in God's eternal gaze? Is not true temporal and causal precedence 'flattened'by the Boethian proposal that God eternally knows the whole of reality in his non-sequential gaze? And is not this flattening consequence a powerful argument against divine timeless eternity in its Boethian variety?

This problem of the flattening of temporal agency is not to be confused with yet another familiar problem of the relation of God's knowledge to time, the problem of how a timelessly eternal God can faithfully represent temporal indexical expressions used in accordance with an A-series understanding of time. How can a timeless God know what is going on now, and if he cannot, how can he be said to be truly omniscient? Even if we can solve this question by an appeal to a B-series understanding of 
time, according to which temporal indexical propositions do not represent temporal reality as it is, there remains the problem of how God can represent to himself in timeless fashion something that most $\mathrm{A}$-series and $\mathrm{B}$-series theorists hold in common, and that presumably Boethius himself held, the reality of causal processes, and of the unidirectionality of time.

\section{Padgett's interpretation of Timeless Statements}

Someone who accepts the force of an argument that is the same or very similar to the flattening argument is Alan Padgett, who uses it to cast doubt on the B-series view of time which any account of divine timelessness, not only Boethius's, seems to require. Considering what Padgett says will be helpful in our efforts to understand Boethius's views. However his treatment of the issue arises in a way that is not specially or directly theological. We shall consider it first in this non-theological variant and make a theological application of it later on.

As Padgett sees it, the problem of flattening, the problem of the genuineness or otherwise of causal powers, arises over a prima facie conflict between the reality of temporal agency and the representation of that agency by expressions that are timelessly true. In explanation of an argument offered in defense of the B-theory of time Padgett writes

The argument (of the B-theorist) seems to run that, since something is a fact at time $T_{3}$, and it is thus always a fact and can be expressed by a true statement that is always true, then in some way the fact of "the fact at $\mathrm{T}_{3}$ " must always exist. ${ }^{11}$

I shall try to show that there is a way to avoid the flattening that Padgett holds to be a consequence of the B-theory. But this way, (as I shall also try to show) is not open to Boethius's argument.

Padgett holds that it is an unfortunate and indeed a fatal consequence of the B-theory of time, which holds that all times are equally real, that what happens at those times is now happening at them.

${ }^{11}$ Alan Padgett, God, Eternity and the Nature of Time (London, Macmillan, I992), II7. 
Thus the difference between the stasis and the process views of time can be put this way: is it now a physical state of affairs that the sun rises (tenselessly!) on the $4^{\text {th }}$ of July 1776 ? The process theorist says "No," and the stasis theorist says, "Yes." For the stasis view insists that, in some way or other, the event of the sun's rising exists (tenselessly) on the $4^{\text {th }}$ of July $1776 .^{12}$

On this interpretation of the B-theory it is committed to the consequence that the sun is tenselessly rising at dawn on the $2^{\text {nd }}$ of July 1776 , tenselessly setting at dusk on the same day, and so on. This, besides being a false belief, or at the very least confused or counter-intuitive (the point Padgett insists on), also seems to rule out the reality of human agency and of causal efficacy more generally, but for a rather different reason than Boethius's argument rules it out. (Though Padgett does not as far as I can see draw out any particular implications that his understanding of the theory has for human agency, but rather concentrates on the unacceptable consequence it has for the B-theory (as he sees it), that physical processes such as those implied by 'it is raining' tenselessly exist. ${ }^{13}$ This he believes runs counter to our ordinary beliefs about time which favour what he calls the process view of time (the A-theory). For if the setting of the sun at dusk on the $2^{\text {nd }}$ of July I 776 is happening tenselessly how could it have been up to some causal factors having to do with the movements of the planets to ensure that it happens at that time?

Padgett believes that this unacceptable consequence of the B-theory is due to the confusion by $\mathrm{B}$-theorists of concrete episodes with propositional states. A concrete episode is the event of John shaving on the $22^{\text {nd }}$ of July 200I. A fact from a logical point of view is the true statement 'John is shaving on the $22^{\text {nd }}$ of July $200 \mathrm{I}$ '; this is a propositional state. But this true statement is in fact an abstraction, not to be confused with the concrete, physical event that is John shaving. Padgett thinks that the B-theory does and must confuse the two, and that the theory carries the unacceptable consequence that every event in the entire temporal order is happening tenselessly. Hence the flattening.

However, according to Padgett what is true tenselessly is not the physical occurrence, but the abstract expression of that occurrence. From the B-theorist's alleged confusion between concrete events and their

${ }^{12}$ Ibid., II8. The 'stasis view' of time is the B-theory, the 'process view' the A-theory.

13 Ibid., II8-9. 
abstract representations Padgett concludes that the B-theorist is confusedly committed to the claim that from the abstract timeless proposition 'The sun rises on the $2^{\text {nd }}$ of July 1776 ' (an expression the truth of which both the A-theorist and the B-theorist may accept) there is now the concrete physical state of affairs of the sun rising (tenselessly) on the $2^{\text {nd }}$ of July I776, (or for that matter on the $2^{\text {nd }}$ of July 2076).

He believes that if these two realms of the physical and the logical are kept separate, then the abstraction, the timeless truth, carries no ontological implications of the sort that he believes that the B-theorist is burdened with, and enables us to avoid the mistaken view that all times are equally real. 'The main problem with the stasis theory (i.e. the B-theory), then, is that it confuses physical "fact" (physical states of affairs) with "fact" from a logical point of view (truths). ${ }^{14}$ The B-theory would then reduce to the more commonsense A-theory according to which only the present is real.

Padgett is surely correct to say that the physical and logical ought not to be confused, but it is hard to see that this point is at all relevant to his argument against the B-theory, which rests upon a particular understanding of tenselessness, and upon the imputation of this view to reality itself, as I shall now go on to try and show. ${ }^{15}$ The first move is carefully to understand the way in which Padgett interprets what he calls timeless statements, and to identify its weaknesses. The second is to note that even if what he says about the nature of tenselessness were true, it is only relevant on the assumption that grammar is an infallible guide to the nature of reality, a point which the new version of the B-theory of time denies. For it does not hold that indexical sentences can be shown to have the same meaning as their non-indexed counterparts. ${ }^{16}$ So even if Padgett's argument is successful against some versions of the B-theory it is not successful against all versions.

${ }^{14}$ Padgett, God, Eternity and the Nature of Time, n18.

15 I have been helped to see this by Nathan Oaklander, „Freedom and the New Theory of Time“, in Questions of Time and Tense, ed. Robin Le Poidevin (Oxford, Clarendon Press, I998).

${ }^{16}$ For convenient discussion of the 'new' B-theory see the Introduction to The Philosophy of Time, ed. Robin Le Poidevin and Murray Macbeath (Oxford: Oxford University Press, 1993). 
Let us look first, then, at Padgett's interpretation of timeless statements. The B-theory of time argues that contingent truths about temporal events are tenselessly true. But how is this idea of tenselessness to be understood? In order to answer this we need carefully to attend to the idea of sempiternity, or at least to one particular understanding of sempiternity. I shall try to show that Padgett's assumption that the tenselessness of the B-theory is to be explicated in the sempiternal fashion that he supposes is unwarranted.

It is possible to construe the idea of sempiternity in at least two distinct ways. An object $\mathrm{O}$ may be said to exist sempiternally when it exists at all times. Alternatively, $\mathrm{O}$ may be said to exist sempiternally if, for any time, $\mathrm{O}$ exists at that time. On the first view, if $\mathrm{O}$ is sempiternal then it exists both in 1066 and 2066, and at all other times. (Let us call this view universal sempiternity (US)). On the second view, if $\mathrm{O}$ is sempiternal then it exists when it is 2066 and exists when it is Io66, and likewise for all other times. But $\mathrm{O}$ does not exist at all those times at once. We can call this view particular sempiternity (PS)

Padgett's interpretation of what he calls timeless statements is clearly a US interpretation of them, as can be seen from how he understands the B-theory. According to him the stasis view (or B-theory) is committed to the view that it is now a physical state of affairs that the sun rises (tenselessly!) on the $4^{\text {th }}$ of July I776. Yesterday it was a physical state of affairs that the sun rises (tenselessly!). Tomorrow it will be a physical state of affairs that the sun rises (tenselessly!). And so on. On US if something occurs at some time it occurs at all times. Padgett claims that on the stasis or B-theory view of time all physical states of affairs now exist, ${ }^{17}$ which presumably means that the physical universe now exists at all times. That is, on Padgett's view the B-theory entails an indexical version of sempiternity. Everything that occurs has sempiternal implications, for it now exists at all times.

However, it is possible to understand the verb in a sentence such as Padgett's 'The sun is rising on the $4^{\text {th }}$ of July I 776 ' in a different way. It may also be interpreted in US fashion, as 'On the $4^{\text {th }}$ of July 1776 the sun is rising'. On either construal, statements made using this sentence have an unchanging truth value, and are consistent with the B-theory's

${ }^{17}$ Padgett, God, Eternity and the Nature of Time, II8. 
commitment to the equal reality of all times. But the B-theory is not as such committed to one interpretation as against the other. Clearly if a B-theorist were to opt for the PS rather than the US interpretation of sempiternity then he may not be saddled with the undesirable consequence of the US interpretation of sempiternity, that the whole of physical reality now exists. He may rather hold that it is true for all times that what exists at 1066 exists at 1066. So there is no convincing reason to suppose that it is a consequence of the B-theory that all events now exist tenselessly in the way claimed by Padgett.

The second point against Padgett is to show that the way in which he interprets his tenseless sentence, in US fashion, assuming that reality itself must have this character, is in any case mistaken. What lies behind this second confusion of Padgett's is the assumption that grammatical tense (or tenselessness) is a good guide to the nature of reality. It needs to be emphasised, as the so-called 'new'B-theory of time does, that grammatical tense and metaphysical reality are distinct; unlike the older B-theory, it is not claimed by the 'new'B-theory that grammatical tense (or indexicality more generally) is eliminable without loss of meaning. Rather, the use of tense and indexicality is indispensable for the way we engage practically with the world, but such a use does not imply that reality as such is tensed. If for good reason reality is judged to be tenseless, this does not mean that we are thereby barred from employing tensed and indexical discourse. Padgett assumes a close connection between grammar and ontology which is more characteristic of the older B-theory. So there is a need to resist the conflation between grammar and reality. There is indeed, as Padgett claims, a distinction between a 'fact' from a logical point of view and a 'physical' fact. A 'fact' from a logical point of view is the truth expressed by a true statement. Thus it is a 'fact' that $2+2=4$, or that London is south of Cambridge'. ${ }^{18}$ But, as Nathan Oaklander points out ${ }^{19}$ Padgett could only imagine that there is a problem here in the first place by confusing (or exclusively identifying) tenseless language with omnitensed (or US) language and then conflating omnitensed language with temporal reality.

18 Padgett, God, Eternity and the Nature of Time, II8.

19 Oaklander, „Freedom and the New Theory of Time“, I9I. 
Despite all this, one may nevertheless be tempted to think that the basic contention of the B-theory, that all times are equally real, takes away causal power. The events of 2004 are all equally real, so how can one event depend on another? But as Oaklander argues ${ }^{20}$, the only necessary conclusion about the events of 2004 that can be drawn from the B-series view is not that necessarily they will be such and such but rather the necessity of the principle of bivalence applying to any description of the events of 2004. But it is a fallacy to argue from $(\mathrm{N}(\mathrm{p} \mathrm{v}-\mathrm{p}))$ (The Principle of Bivalence) to $\mathrm{Np}$ or from $(\mathrm{N}(\mathrm{p} \mathrm{v}-\mathrm{p}))$ to $\mathrm{N}-\mathrm{p}$. If one possible event of 2004 is that I shall mow the lawn on the $22^{\text {nd }}$ of July then it is my decision to mow the lawn on that occasion that renders 'Helm mows his lawn on the $22^{\text {nd }}$ of July 2004' true. Our ignorance of the future is not simply the ignorance of some truths about the future, but it is also ignorance of the exact nature of the causal forces which we ourselves are subject to and contribute, as well as of the outcomes of those causal forces.

So in what sense are all times equally real for the B-theory? Not necessarily in the US sense that what exists does so at all those times, but possibly in the PS sense. On the $22^{\text {nd }}$ of July 2002 what exist are those states and events which are contemporaneous with that date. What exists on the $23^{\text {rd }}$ of July 2002 does not in virtue of that fact also exist on the $22^{\text {nd }}$ of July 2002, or now, if now is different from the $22^{\text {nd }}$ of July 2002. And we can be sure that what exists on the $23^{\text {rd }}$ of July 2002 partly or perhaps wholly depends on what exists on the $22^{\text {nd }}$ of July 2002 . To say that events which occur on these dates are equally real is to make what is in essence a negative point; that not one of these times is privileged (by being present, or now, for example) over any of the others. It may be said that NIS expresses a trivial truth, the trivial truth that for all times, whatever exists at a time $\underline{t}$ exists only at $\underline{t}$, but a trivial truth is surely preferable to a non-trivial falsehood.

But what if we are thinking of such sentences not as merely tenselessly true, and so (in that sense) equally as real as each other, but also that the truths they express are, in Boethian fashion, eternally and immediately seen by a timeless God, as someone on a hillside sees an array of events before him? Does this not mean that all times exist in the way that

${ }^{20}$ Oaklander, „Freedom and the New Theory of Time“, I94. 
Padgett argues flattens human agency? Let's now return to this question and examine it a bit more closely. Perhaps it does. Perhaps Padgett has a point after all.

\section{GOD'S TIMELESS REPRESENTATION OF THE TEMPORAL ORDER}

We must now transpose this discussion of tenselessness and sempiternity into the theological key of Boethian divine eternality. Earlier it was suggested that given such a God's timelessly immediate epistemic relation to the temporal universe that universe must be an object of non-sequential knowledge. For God there is no past or future. He gazes onto the whole temporal order, seeing it immediately. But if he non-sequentially perceives everything how can any event be earlier than or later than any other? The further question is, does such a God have a use for the temporal relations of earlier than/later than beloved of the B-theorist? As we have seen, on a plausible construal of the B-theory of time all events occur determinately at the moment that they $\mathrm{do},{ }^{21}$ the future is as fixed as the past. The view is committed to the principle of bivalence according to which necessarily every proposition is either true or false. So that necessarily it is true (or false) that I will eat a tuna sandwich for lunch a year from tomorrow, January the 15 th 2004. All objects have a tenseless existence, and nothing really changes, where change is accounted for by sequentially different features of perduring objects. Paul's change from being hirsute to being bald is accounted for by Paul being hirsute at $t_{I}$ and Paul being bald at $t 2$.

This is a metaphysical view about the nature of time and change. And if it is the true view then we might at first suppose that a Boethian timelessly eternal God, who sees things as they are, represents the created order to himself, insofar as it is considered a temporal order, in this fashion. So let us suppose that this eternal representation, whatever its exact character in the divine mind, is isomorphic with the tenseless expressions of our language used to represent temporal orderings. But how can this be? How can God immediately perceive that X is later than $\mathrm{Y}$ if he perceives $\mathrm{X}$ and $\mathrm{Y}$ in one timelessly eternal, non-inferential vision? Perhaps there is

${ }^{21}$ Oaklander, „Freedom and the New Theory of Time“, I85. 
an answer to this question. As we have noted in discussion of Padgett, it is not nowadays usually argued by holders of the B-theory of time that tensed language can be eliminated, because it is recognised that tensed language is a necessary feature of how we practically cope with the world. But the need for such tensed language does not mean that there are, in reality, tensed properties. All temporal properties, it is argued by the B-theorist, are tenseless. Might we not deploy this point in defence of Boethius's idea of God? Just as the B-theorist may use the language of tense without being committed to the A-series view of time, so may not God use timelessly eternal representations of his creation without being committed thereby to the elimination of temporality in his creation? God's eternal vision is then a mere divine façon de penser. Perhaps God is a 'new' B-theorist!

However, maybe this attempt to rescue Boethius does not make sufficient allowance for the fact that these visually immediate, non-inferential representations in the divine mind are held by Boethius to be states of knowledge, states of mind of one who is both omniscient and infallible. If this is so, does it not strictly follow, and not loosely follow as a mere façon de penser, that if we suppose that God has a timeless, visually immediate awareness of some event $A$, then the object of awareness must be timelessly eternal? If this is how it appears to God, then this is how it is. So our earlier dilemma recurs. Either God is fallible and not omniscient, or the temporal order is an illusion. Despite Boethius's insistence that divine knowledge does not change the nature and property of thing $\mathrm{s}^{22}$, it seems that it cannot fail to change them, or to represent them other than they are. Taking a cue from this, some may argue that a timelessly eternal God is doubly ignorant: ignorant of the truths expressed by temporal indexicals, and ignorant of truths expressed by statements of temporal causal agency. The Boethian will be wise to dismiss the first of these areas of ignorance, for in his view there is nothing that a temporal indexical sentence expresses that cannot be as well expressed in a tenseless sentence. But ought not he nonetheless to be bothered by this second area of alleged divine ignorance?

However, before we rush to the conclusion that God's immediate (in the sense of non-sequential) knowledge of the world implies that the world

${ }^{22}$ Consolation, 166. 
itself is non-sequential we may reflect on a more basic fallacy that lies at the heart of this anti-Boethian argument that we have been pursuing. It is the fallacy of concluding that because knowledge is obtained under certain conditions therefore what is known, the object of that knowledge, must also possess these conditions. If what I see I certainly see, it does not follow that what I see is certain. I may certainly see something the character of which is uncertain. I might certainly see a blur in my visual field and be uncertain whether or not the blur was a bear. More to our present point, if what I see I presently see, it does not follow that what I see is present. I may presently see a bright light, but the light may be the light of a star which no longer exists. More generally, it is fallacious to argue that since all my experience is present experience I can only have knowledge of what is present. How is it that I can know truths about the past even though all my experience is present experience? Because it is possible for me to make inferences from the present to the past. So we cannot confidently conclude that if God non-sequentially knows that $\mathrm{E}$ occurs and that $\mathrm{F}$ occurs that $\mathrm{E}$ and $\mathrm{F}$ cannot be two events one of which is later than the other.

\section{A SECOND SENSE OF 'IMMEDIACY'}

Not until, that is, we take into account a second sense of immediacy which is implied in the various expressions-'boundless immediacy', 'one simultaneous present', 'the divine gaze'-which are at the heart of Boethius's account. As we have seen a central point made by Boethius is that the knowledge that a knower has depends for its character not only on what is known, (nor, we might add, on the metaphysical condition of the knower, timeless or otherwise), but also on the epistemic powers of the knower. God's eternality is such that all his knowledge of his entire creation is immediate in the further sense that he knows what he sees without the intervention of any inferential element. This further sense of immediate is also, for Boethius, central to our appreciation of how the eternal God knows. I shall argue that it is this second sense of immediacy, a perception of the entire creation that is non-inferential, that poses the ultimate difficulty for his account of how God knows the created order. 
This is what Boethius says about this sort of immediacy. It is knowledge 'free from all corporeal influence'. ${ }^{23}$ Beings in this position do not have to react to external stimuli in order to perceive things. Integral to Boethius' account is a hierarchical view of knowledge according to which the manner in which non-human animals know (by imagination) is different from the way in which humans know (by reason), and how humans know is different from the way in which God knows (by intelligence). ${ }^{24}$ Divine knowledge has 'boundless immediacy'. ${ }^{25}$

God's knowledge, therefore embraces all the infinite recesses of past and future and views them in the immediacy of its knowing as though they are happening in the present.......It makes no confused judgments of things, but with one glance of its mind distinguishes al that is to come to pass whether it is necessitated or not. ${ }^{26}$

God's knowledge does not change, as you think, with alternate knowledge of now this and now that, but with one glance anticipates and embraces your changes in its constancy ... The power of this knowledge which embraces all things in present understanding has itself set a limit upon things and owes nothing to events which come after it. ${ }^{27}$

The two senses of immediacy, non-sequential and non-inferential, need to be kept distinct, because while God could non-sequentially perceive the temporal creation as a whole, he could not do so except by inference. But all of God's knowledge, Boethius strongly implies, is non-inferential. So it would seem that if this is so our earlier objection is reinstated. God could perceive the creation without sequence as a result of inference, but the knowledge he gains by such a 'gaze' must be non-inferential knowledge.

Since, therefore, all judgement comprehends those things that are subject to it according to its own nature, and since the state of God is ever that of eternal presence, His knowledge, too, transcends all temporal change and abides in the immediacy of His presence. It embraces all the infinite recesses of past

\footnotetext{
23 Consolation, I6r.

24 Consolation, $16 \mathrm{I}-2$.

25 Consolation, 162.

26 Consolation,165-6.

27 Consolation, 168.
} 
and future and views them in the immediacy of its knowing as though they are happening in the present. ${ }^{28}$

It will be recalled that Boethius contrasts the divine life, which embraces the whole of everlasting life in one simultaneous present, and the infinite changing of things in time. 'It cannot possess simultaneously the whole fullness of its life, but by the very fact that it is impossible for its existence ever to come to an end, it does seem in some measure to emulate that which it cannot fulfill or express' ${ }^{29}$ But perhaps this contrast cannot be quite as stark as Boethius makes out. If his view about the eternal God's knowledge carries the implications argued for earlier, must he not give up his doctrine of the sempiternity of the world? Yes and no. Yes, as an account of the temporal character of the created order ('the infinite changing of things'). But not as a way of characterising the contingency of that order. ${ }^{30}$ The temporal order, this eternal, non-temporal series of times, might not have been. But for Boethius it doesn't exist across all times, nor does it exist at a time, it exists timelessly eternally, the created counterpart of God's eternally timeless life. So I venture to suggest that one consequence of his view of divine knowledge is that it is inconsistent with other things he wishes to stress, namely, that God is eternal while the world is perpetual. ${ }^{31}$ On his account of divine knowledge, the world, though contingent, must be an immediate percept of the eternally divine mind.

What creates the problem for Boethius is not the use of the language of visual perception but his insistence that such perception is non-sequential and non-inferential perception. When we combine these two sorts of immediacy, perception without sequence and perception without inference, then it follows that the percepts, the individual objects of immediate perception such as events, cannot be percepts of what is temporally ordered. It is not possible to immediately perceive the entire temporal order 'at once' and also to immediately recognise it (in the perceptual sense) as a temporal order. This is the flaw.

28 Consolation, 165.

${ }^{29}$ Consolation, $164-5$.

${ }^{30}$ Assuming, that is, that Boethius holds that the world, though infinite in time, is nevertheless contingent.

31 Consolation, 165. 
Why Boethius insists on this double immediacy is clear: in his view his apologetic strategy for the reconciliation of divine providence and human responsibility requires it. But other than that, it would seem that Boethius has at least the option of thinking of God's knowledge of the temporal order in more straightforwardly intellectualist terms: as involving understanding, or judgment. On such a view although God does not immediately perceive the temporal order, he eternally judges that it is temporal. Sticking to Boethius's analogy between divine knowledge and visual perception, this would be to understand divine immediate perception along the lines of Fred Dretske's 'simple seeing' (where if A simply sees $\mathrm{X}$ he need have no beliefs about $\mathrm{X})^{32}$ together with sets of immediate and infallible beliefs about X. God simply sees time-bound individuals and temporal sequences and has infallibly true beliefs about this temporality. In addition, presumably God infallibly knows that he simply sees what he sees. God's knowledge is immediate in that both the seeing and the beliefs held about it are timelessly eternal, though it is not immediate in the sense of being non-inferential. This approach seems more promising: but at the cost of forfeiting Boethius's apologia for the compatibility of divine foreknowledge and human freedom.

Summarising, I have argued that if we take the Boethian notion of immediate perception as the way to understand a timeless God's knowledge of the temporal order, then this results in a flattening of the temporal order, the elimination of its true temporality. This flattening is different from that mistakenly alleged by Padgett in his criticism of the B-theory, which is a sempiternal flattening, according to which every event occurs at all times. On the Boethian view, since God, being infallibly omniscient, knows the world exactly as it is, in that world everything may 'occur' in a sequence, though not in a truly temporal series, but in one that is more like an arithmetic series. Only if God's knowledge is obtained through inference may this conclusion be avoided. But Boethius is clear that God's knowledge is non-inferential. He must thus surrender his contrast between eternity and perpetuity, for the world is as timelessly eternal as God himself is.

${ }^{32}$ Fred Dretske, „Simple Seeing, “ in Perception, Knowledge and Belief (Cambridge: Cambridge University Press, 2000). 


\section{Augustine}

What of that other fountainhead of the idea of divine timeless eternity? Although in Book XI of the Confessions Augustine occasionally uses the analogy of vision to offer some understanding of what divine timelessly eternal knowledge is like ${ }^{33}$ the analogy which appears to interest him much more is that of speech, and in particular our knowledge of our own speech, whether or not we express this publicly. He concentrates on this in the closing sections of Book XI, from xxvii (34) to the end, at that stage when, he thinks, the truth is beginning to dawn regarding the measurement of time. He takes the analogy of a voice sounding out. 'It sounds. It continues to sound, and then ceases. Silence has now come, and the voice is past. There is now no sound. Before it sounded it lay in the future. It could not be measured because it did not exist; and now it cannot be measured because it has ceased to be' ${ }^{34}$ But neither can a voice that is still sounding be measured. Yet when it comes to an end, then it has ceased to be. And how can what has ceased to be be measured? How then can the voice be measured?

Nevertheless we do measure periods of time. And yet the times we measure are not those which do not yet exist, nor those which already have no existence, nor those which extend over no interval of time, nor those which reach no conclusions. So the times we measure are not future nor past nor present nor those in process of passing away. Yet we measure periods of time..$^{35}$

And if we suppose not merely a sound, but sung or spoken words, how shall we know that one of the syllables of those words is twice as long as another? 'How shall I keep my hold on the short, and how use it to apply a measure to the long, so as to verify that the long is twice as much? The long does not begin to sound unless the short has ceased to sound'. ${ }^{36}$

What do I measure when I measure the fact that one syllable is twice as long as another, when both syllables are past and have 'flown away'? ${ }^{37}$

\footnotetext{
33 Augustine, Confessions, e.g. 221.

34 Confessions, 240.

35 Confessions, 24I.

36 Confessions, 24I.

37 Confessions, 242.
} 
It can't be the syllables I'm measuring because they have passed away, but something which is present, my memory of them. 'The impression which passing events make upon you abides when they are gone'. ${ }^{38}$ And we can do this when we do not utter any sound, as when we mentally recite poems. I can decide to utter a sound lasting for ten seconds, and then utter it. In doing this, the mind expects, and intends and remembers, as the sound is sounded out. So, Augustine says, my life is a distension in several directions. ${ }^{39}$ And Augustine draws a vivid contrast between the turmoil of earth and the tranquility of heaven. 'The storms of incoherent events tear to pieces my thoughts, the inmost entrails of my soul, until that day when, purified and molten by the fire of your love, I flow together to merge into you'. ${ }^{40}$

But what of God himself? What of his eternal knowledge of the temporal order?

Certainly if there were a mind endowed with such great knowledge and prescience that all things past and future could be known in the way I know a very familiar psalm, this mind would be utterly miraculous and amazing to the point of inducing awe. From such a mind nothing of the past would be hidden, nor anything of what remaining ages have in store, just as I have full knowledge of that psalm I sing. I know by heart what and how much of it has passed since the beginning, and what and how much remains until the end. ${ }^{41}$

Is this how it is with God, for Augustine? Does he know as we know, only more so? 'But far be it from you, Creator of the universe, creator of souls and bodies, far be it from you to know all future and past events in this kind of sense. You know them in a much more wonderful and much more mysterious way.....Just as you knew heaven and earth in the beginning without that bringing any variation into your knowing, so you made heaven and earth in the beginning without that meaning a tension between past and future in your activity'. ${ }^{42}$ And that's how Augustine leaves it.

\footnotetext{
38 Confessions, 242.

39 Confessions, 243.

40 Confessions, 244.

${ }^{41}$ Confessions, 245.

42 Confessions, 245 .
} 
Augustine holds to divine timeless eternality just as fervently as Boethius but he is much more guarded and agnostic, even sceptical, about how to understand such divine knowledge than Boethius. He certain does not favour the idea of immediate visual perception. He is, it seems, much less confident that we have the capacity necessary to elucidate it. And in view of the difficulties that follow from Boethius's understanding of God's eternal knowledge as a case of immediate perception, such reserve would seem to be the wiser stance.

How does God know the temporal order? It is tempting to answer that he knows because for him the temporal order is 'spread out in time'. But as we have seen in our discussion of Boethius, this is to spatialise time in a misleading way. Rather, it is better to use temporal analogies for God's knowledge of the temporal order if these are available. Augustine tries these analogies, and has what seem to be reasons to think that they don't work. In these circumstances is it not wiser to offer no analogies at all?

Who can lay hold on the heart and give it fixity, so that for some little moment it may be stable, and for a fraction of time may grasp the splendour of constant eternity? Then it may compare eternity with temporal successiveness which never has any constancy, and will see there is no comparison possible. ${ }^{43}$

Thanks are due to Oliver Crisp and Katherin Rogers for their suggestions on earlier drafts.

\section{BibLIOgRAPHY}

Augustine. Confessions. Translated by Henry Chadwick. Oxford: Oxford University Press, World's Classics, 1992.

Boethius. The Consolation of Philosophy. Translated by V.E. Watts. Harmondsworth: Penguin, 1969.

Burrell, David, CSC. Freedom and Creation in Three Traditions. Notre Dame, IN:

University of Notre Dame Press, 1993.

Dretske, Fred. „Simple Seeing.“ In Perception, Knowledge and Belief. Cambridge: Cambridge University Press, 2000.

${ }^{43}$ Confessions, 228 
Kneale, Martha. „Eternity and Sempiternity.“ Proceedings of the Aristotelian Society 1968-9.

Oaklander, Nathan. „Freedom and the New Theory of Time." In Questions of Time and Tense, edited by Robin Le Poidevin. Oxford: Clarendon Press, 1998.

Padgett, Alan. God, Eternity and the Nature of Time. London: Macmillan, 1992.

The Philosophy of Time. Edited by Robin Le Poidevin and Murray Macbeath. Oxford: Oxford University Press, 1993. 